\title{
Major Contributions of the University of Wisconsin to Biomedical Science
}

\author{
E Richard Stiehm MD* \\ Department of Pediatrics, David Geffen School of Medicine, California
}

*Corresponding author: E Richard Stiehm MD, Distinguished Research Professor Emeritus, Department of Pediatrics, David Geffen School of Medicine at UCLA, Los Angeles, California

To Cite This Article: E Richard Stiehm, Major Contributions of the University of Wisconsin to Biomedical Science. 2020 - 10(6). AJBSR.MS.ID.001575. DOI: 10.34297/AJBSR.2020.10.001575.

Received: 眥 October 29, 2020; Published: 眥 November 17, 2020

\section{Opinion}

The University of Wisconsin, Madison (UW) is the flagship University of the State of Wisconsin. It is one of the largest and bestknown public universities in the USA with 30,000 undergraduate and 15,000 graduate students. These include many students and visiting scholars from foreign countries. Its research spending is among the top ten universities in the USA. As a former undergraduate, medical student, and faculty member of the UW, I gained a deep appreciation for its many contributions to biologic science and medicine. Several of the individuals that were responsible for these advances are detailed below. Many were my teachers and colleagues. I have divided the individuals these advances into four categories, The Vitamin Discoverers, The Cellular Biologists, The Physician Scientists and The Organization Leaders.

\section{The vitamin chemists}

Harry Steenbock PhD (1886-1967) Professor and Chair of Agricultural Chemistry

Harry grew up on a farm near New Holstein, Wisconsin. When he was 17 his father had an offer the farm, so he asked Harry if he wanted to eventually take over the farm. The answer was.an emphatic NO! So, the family sold the farm and moved to Madison so Harry could enter the University. He graduated from the School of Agriculture in 1908 and then worked for Professor Edwin Hart of the Agriculture School on the for farm animals, receiving a PhD in 1916.

He continued his studies on animal nutrition by studying animal models of vitamin deficiencies. He read that experimental dietary rickets, a deforming bone disease, could be reversed by ultraviolet radiation of the animals, The sun's rays allowed their skin to make Vitamin D. Dr. Steenbock then made his break-through observation that the same effect could be achieved by irradiating their feed animal's; this converted fat lipids in in their feed to vitamin D. He then showed that irradiated cow milk could Create make Vitamin D, and this would provide a ready source vitamin D in the diets of both children and adults.

Using his own funds Dr. Steenbock patented this procedure in 1927. The Quaker Oats Company offered him the equivalent of three million dollars for the patent; instead he turned it over to the University of Wisconsin. Several prominent UW alumni, headed by Thomas Brittingham, started a foundation to manage the royalties from that patent for the next 27 years. The foundation was named the Wisconsin Alumni Research Foundation (WARF) WARF now holds multiple patents and provides the university 100 million dollars of research funds every year and has been became a major funding source for UW research, particularly during the depression years, (1933-1939), but continuing to the present. WARF now holds multiple patents and provides the university 100 million dollars of research funds every year. The Agriculture/Life Science library is named after Dr. Steenbock. His former student and successor Hector DeLuca PhD holds the Steenbock Endowed Chair and now is the foremost authority on Vitamin D and its derivatives as used in the therapy of multiple disorders.

\section{Karl Paul Link PhD (1901-1978) Professor of Agricultural Chemistry}

Karl was born in La Pointe, Indiana, one of eight children. His father was a Lutheran minister who died when Karl was twelve. With family support and his mother's admiration for Senator Robert LaFollette, Karl entered the University of Wisconsin, receiving a BS in 1922, a MS in 1924 and a PhD in 1925 in carbohydrate chemistry. 
After postdoctoral work in Europe, interrupted by a hospitalization in Switzerland. for tuberculosis, he joined the UW faculty in 1927 He soon distinguished himself by his non-traditional clothing (large bow ties, flannel shirts, work shoes and a cape) a booming voice, long hair and radical views, all of which kept his students amused and attentive, His international fame began with the legendary story that a cold Saturday in February 1933. Farmer Ed Carson had drove his truck 200 miles in a snowstorm to the UW Agriculture building to confront Professor Albert Carson (no relation) the only one in the building that Saturday. He also brought along a dead heifer (cow), a bucket of its uncoagulated blood and 100 pounds of fermented sweet clover hay. He told the professor "This hay is making my cows bleed to death." The cows had the previously described Sweet clover disease, Professor Carson turned this problem over Dr. Link. Over the next 6 years, Dr. Link and his colleagues isolated the factor in the clover that caused the bleeding a natural substance called dicoumarol, an inhibitor of Vitamin $\mathrm{K}$, which is necessary for blood coagulation. Their laboratory synthesized enough dicoumarol to be tested, as an anticoagulant, first in animals, and then in humans. Its first use was as a rat poison, causing the critters to bleed to death.

The Link laboratory synthesized and tested many related compounds and settled on one, Coumadin, which was a potent anticoagulant with that was orally absorbed, fast acting and quickly reversible by vitamin K. It was licensed for human use in 1954 and patented by the Wisconsin Alumni Research Foundation as WARFARIN. It soon became the most widely used blood thinner in the world. The drug received widespread acceptance after it was used on President Dwight Eisenhower after his heart attack. Its proceeds allowed the Foundation to grow just as the patents on irradiation of milk were expiring. The best tribute to Karl Paul Link is the WARF building on the UW campus, in part financed by the patent for WARFARIN, the most widely used blood thinner in the world.

\section{Conrad Elvehjem PhD (1901-1962) Professor and Chair of Agricultural Biochemistry, Dean of the Graduate School, UW President}

Conrad was born in McFarland, Wisconsin to Norwegian emigrants. He received a BS in 1924 and a PhD in 1927. He then joined the Agricultural Biochemistry faculty and served as its chair, as Dean of the Graduate School and then served as the 13th UW President from 1958 to 1962 . Dr. Elvehjem worked on the cause of pellagra, a nutritional disease-causing dementia, dermatitis and diarrhea with early death ie the four D's. It was common among people living on a corn diet deficient in fruits and vegetables; this included many persons in prisons and asylums.

Earlier work by Dr. Joseph Goldberger had cured a similar disorder in dogs, called black tongue disease by a liver extract. Elvehjem then showed that a liver extract could cure dietary pellagra in chicks and this could be used to identify the exact component of the liver extract that prevented pellagra in chickens. Elvehjem isolated and characterized this as niacin, Vitamin B3. Niacin was then used worldwide to treat and prevent pellagra, including curing some demented and institutionalized patients. Dr. Elvehjem became a major advocate for the need for vitamins in the diet. He authored 780 papers and trained multiple graduate students. His first graduate student was Frederick Stare PhD. who founded and chaired the Department of Nutrition of the Harvard School of Public Health?

\section{The cellular biologists}

Har Gobind Khorana PhD (1922-2011) Professor of Biochemistry, Director of the Enzyme Institute

Har was born In Raipur, a little village in India's Punjab, now part of Pakistan. The family was the only literate one in a village of 100. He received early schooling under a tree from a village teacher. Har received a BS and MS from Punjab University and then moved to the UK in 1945, receiving a PhD in 1948 from the University of Liverpool. After positions in Zurich, Cambridge, and British Columbia he came to UW in 1952 to head the WARF-supported Enzyme Institute.

Dr. Khorana's work focused on the DNA genetic code, determining the sequence of the four DNA nucleotides which direct the synthesis of the 21 amino acids, the building blocks of all proteins. He then synthesized the first artificial DNA gene. For this work he was awarded the 1968 Nobel Prize with Robert Holley of Cornell and Marshall Nirenberg of the US National Institutes of Health. In 1970 Dr. Khorana moved to the Massachusetts Institute of Technology, focusing on rhodopsin, a visual protein, whose gene, which when mutated causes retinitis pigmentosa and night blindness. He retired in 2007 and died in 2012.

\section{Howard M Temin PhD (1934-1994) Professor of Oncology}

Howard was born and raised in Philadelphia. He received a BS from Swarthmore College in 1955 and a PhD from the California Institute of Technology in 1959. He then joined the UW McCardle Cancer Research Laboratory where he remained until his death from lung cancer in 1994.

Dr. Temin's main contribution was the co-discovery of the reverse transcriptase enzyme of the Rous Sarcoma Virus (RSV) of chickens. In 1911 Dr. Pierre Rous showed that a cell-free extract of this tumor would cause the same sarcoma in another chicken. The cell-free agent was an RNA virus, which, unlike DNA viruses, mutates readily when it makes a DNA copy for its replication. Dr. Temin identified the enzyme reverse transcriptase that catalyzes the RNA to DNA reaction. An inhibitor of this enzyme, zidovudine (AZT) was the first effective drug against the Human Immunodeficiency Virus (HIV) that causes the Acquired Immune Deficiency Syndrome (AIDS). AZT 
given to HIV positive-pregnant women and their newborns greatly reduces the rate of HIV transmission from mothers to their infants. Dr. Temin received the Nobel Prize in Medicine 1n 1975 with David Baltimore of the Massachusetts Institute of Technology and Renato Dulbecco of the London Cancer Research Laboratory. Dr. Temin became a spokesman against smoking as a cause of cancer including it in his Nobel acceptance speech in front of the Queen of Sweden who was a smoker. He died of lung cancer in 1994 at age 59. The lakeside path between the UW student union and Lake Mendota's Picnic Point was renamed in his honor.

Joshua Lederberg PhD (1925-2008) Professor and Chair Department of Genetics Joshua was born in Montclair New Jersey and grew up in New York City. He entered Columbia as an undergraduate and then its medical school. Before completing his medical degree, he transferred to Yale for a $\mathrm{PhD}$ in genetics with Edward Tatum PhD. Instead of returning to medical school he joined the Department of Genetics at Wisconsin, eventually becoming its Chair.

Dr. Lederberg's Nobel Prize studies showed that a bacterial virus (a phage) that made an E. coli bacterium resistant to a specific antibiotic could transfer its resistance to another strain of E coli if grown together in the same culture. These studies were labelled "bacterial sex" and "jumping genes." This transduction, as it is called, can also occur from one strain of bacteria to a completely different type of bacteria, thus explaining the emergence of multi drug resistant bacteria in severely ill patients. Dr. Lederberg received the 1958 Nobel Prize along with his Yale mentor Edward Tatum and George Beadle of the California Institute of Technology. Shortly thereafter he moved to Stanford as Chair of Genetics. After the moon landing, he became interested in the possibility of extraterrestrial microorganisms brought to earth by the astronauts and the development of technology to harvest them. He was named President of Rockefeller University in 1978 and died in 2008.

James Thomson DVM, PhD (1938) Professor of Anatomy, Director Cellular and Regenerative Medicine Institute James was born in Oak Park Illinois. He received a BS from the University of Illinois and a DVM and a PhD from the University of Pennsylvania. After two years at the Oregon Primate Research Center he came to UW in 1991 to complete a residency in Veterinary Pathology. He joined the UW Anatomy Department faculty in 1994 and was named the director of the Regenerative Medicine Laboratory of the Morgridge Research Institute in 2006.

In 2008 Dr. Thomson was the first to culture pluripotent stem cells from human embryonic cells. These cells are immortal and can differentiate into different types of cells such as blood cells, nerve cells and organ cells. Shortly thereafter President Bush vetoed research funding on human embryonic stem cells. In 2013 the Thomson laboratory developed human stem cells from the skin using a cocktail of growth factors.
Dr. Thomson, in conjunction with WARF, established a nonprofit WiCel Research Institute that distributes stem cells to researchers at Wisconsin and other laboratories around the world.

\section{The physician scientists}

Frederic Mohs MD. (1910-2002) Professor of Surgery Fred was born in Darlington in southwestern Wisconsin. His widowed mother moved to Madison so Fred could attend the UW where he received a BS in1930 and an MD in 1932. As an undergraduate he assisted Dr. Michael Guyer of the Zoology Department on skin cancers in rats provoked by chemical exposures. After surgical training at the University of Oregon he returned to UW to continue his work on skin cancer. His breakthrough observation was that rat skin cancers caused by chemical exposures could be treated by local application of a caustic paste of zinc chloride. This not only killed the cancer cells but fixed the tumor for its easy removal to allow microscopic analysis of the tumor edge to see if all the tumor had been removed. If not, the cancerous areas were then retreated, layer by layer, until all the cancer was removed. Further, the cavity left by the tumor was resistant to infection and healed quickly.

One disadvantage was that every reapplication took a day since the slides had to be stained and examined that evening, prolonging the treatment for several days. Dr. Mohs later modified the technique by using frozen sections of the tumor that can be prepared shortly after each application thus allowing the procedure to be completed in a single day. Dr. Mohs treated his first patient in 1936, calling it Chemosurgery. Despite its name, the UW surgical department did not support his work. However, Dean Middleton recognized its importance and gave him a suite in the dermatology division.

As word spread of its success of tumor removal with minimal scarring, patients came from all over the country for their treatment. Dr. Mohs showed his technique to other doctors and soon training programs in chemosurgery were established. Chemosurgery was renamed Mohs micrographic surgery and centers were added all over the country. Over 1500 doctors have been trained in the technique and nowadays it is a recognized subspecialty with clinics at all major medical centers. Harry Waisman MD, PhD (1912-1971) Professor of Pediatrics, Director Joseph P Kennedy Memorial Laboratory for Developmental Disabilities.

Harry, born in Milwaukee received four UW degrees, a BS in 1935, an MS in1937 a PhD in 1939 and an MD in 1941. He then was a pediatric resident before joining the Pediatric Faculty in 1943. He started his research on childhood cancers but switched to hereditary inborn errors of metabolism that cause mental retardation, particularly phenylketonuria (PKU). This disease is caused by an enzyme deficiency needed for the metabolism of the amino acid phenylalanine, causing it to build up in the blood and brain resulting in mental retardation. Carriers of the disease are unaffected but if both mother and father pass on their abnormal 
gene their infant will develop phenylketonuria. The disease can be diagnosed at birth by a heel-stick blood test and treated successfully with a phenylalanine-free diet.

Dr. Waisman was an early researcher on the disease using animal models, methods to detect asymptomatic carriers, newborn diagnosis, and its dietary treatment. PKU was the first disease detected by routine newborn heel stick testing; now every US newborn is tested for PKU and 26 other hereditary diseases. In 1963 the Kennedy Foundation provided funds to UW for the Joseph P Kennedy Memorial Laboratories for Developmental Disabilities directed by Dr. Waisman. Two years later the National Institutes of Child Health and Human Development awarded funds for a multidisciplinary building for research on intellectual and developmental disabilities., The Waisman Center on the medical campus was in 1973, two years after Dr. Waisman's death in 1971.

Folkert Belzer MD (1930-1996) Professor and Chair of the Department of Surgery Folkert was born in Indonesia and moved to the USA as a teenager. He graduated from Maine's Colby College in 1953 of Waterville, Maine in 1953 and then received an MD from Boston University in 1958. followed by a surgical residency and fellowship at the University of Oregon. He joined the transplant team at the University of California, San Francisco, He was named Professor and Chair of UW Surgery, 1974 to 1995 . He and his colleagues developed the third largest transplant center in the USA before his death in 1996. In the 1960s Dr. Belzer developed a perfusion machine that kept donated kidneys viable for several hours permitting the recipient to get to the hospital for the transplant. Using this machine a kidney donated in San Francisco was flown to Holland and successfully transplanted 37 hours later.

At Wisconsin he and colleague Dr. James Southard developed a solution that kept a refrigerated donor organ (a kidney, heart, pancreas, or liver) viable for up to 30 hours. It contained 15 ingredients to nourish the organ, prevent edema, maintain sterility, and prevent enzyme release. Called the Wisconsin Solution it was patented by WARF and distributed as Viaspan by a WARFsupported company named Bridge to Life. Later work included a similar solution for organ preservation at room temperature. These solutions had an enormous role in organ transplantation since the donor organ could be flown to the patient in another city thus facilitating survival rates of 70 to 90 percent.

\section{The organization leaders}

Harold P Rusch MD (1908-1988) Professor of Oncology, Director, McCardle Laboratory for Cancer Research

Harold was born in Merrill, Wisconsin. He became interested in medicine because of his own appendectomy as a youngster. He attended the UW, receiving a BA in 1931 and an MD in 1935. He then joined the Medical School faculty, teaching physiology and beginning his cancer research on the effect of obesity and ultraviolet light as precursors to cancer. In 1938 the McCardle family donated funds to establish a Cancer Research Program and Dr. Rusch at the age of 30 was named its director. In 1949 the McCardle Laboratory for Cancer Research was opened in a building attached to the Wisconsin General Hospital, the first such institute dedicated to cancer research. In 1964 the McCardle laboratory moved to its own building on the medical campus and moved again in 2013 to the newly constructed Wisconsin Institutes for Medical Research on University Avenue.

Dr. Rusch gathered an impressive group of scientists for his laboratory including Van Potter (triple chemotherapy, bioethics), Elizabeth and James Miller (chemical carcinogenesis), Roswell Boutwell (nutrition and cancer), Gerald Mueller (hormonal control of cancer), Charles Heidelberger (development of the drug 5-fluoruracil), V. Craig Jordan (development of the drug tamoxifen), and Howard Temin, (Nobel Prize for discovery of the reverse transcriptase enzyme in RNA cancers). In 1972 Dr. Rusch became the Director of the UW Comprehensive Cancer. Before his retirement in 1970 he recruited Dr. Paul Carbone to continue his work. Dr. Rusch died of cancer in 1988, the disease that he spent a lifetime studying its causes and cures.

William S. Middleton MD (1890-1975) Professor of Medicine, Dean of the University of Wisconsin Medical School

William was born in Norristown Pennsylvania to working class parents. Based on his outstanding, high school record he was directly admitted to the medical school of the University of Pennsylvania in 1907, graduating with an MD in 1911. After a one-year internship at Philadelphia General Hospital he joined the Student Health Service of the University of Wisconsin and served as an instructor in Medicine in its two-year medical school.

In 1924 Wisconsin General Hospital opened and the medical school became a 4year school with Charles Bardeen MD. Professor of Anatomy as the first Dean. In 1935 Dr. Middleton was named the Second dean, a position he held until 1955, interrupted by two leaves of absence to serve in the military. Dr. Middleton was a master teacher bedside teacher, delighting by his students, by his pearls of wisdom and his dime fines for not knowing the answer to his question. He spent mornings in the hospital and afternoons in the Dean's office. From 1917 to 1919 Dr. Middletons served as a Lieutenant in the US Army Medical Corps in France during World War I. In Dr. Middleton, now Colonel Middleton, 1942 again Dr. Middleton, now Colonel Middleton, volunteered for war duty. He was named Chief Consultant in Medicine of the European Theater of Operations stationed in Britain. From there he planned the medical care of casualties of the D-day landing of June 6, 1944. 
Shortly after the invasion Colonel Middleton went to Normandy for several months to supervise the care of 2600 medical and 2000 neuropsychiatric casualties. Upon his return to Britain, he coordinated the hospital care of battle casualties up through 1945. One of his patients was General George Patton who he diagnosed with malaria. For his military service he was awarded an Honorary Office of the British Empire (military), the Croix de Guerre from France, the Lion of Merit with Oak Leaf Cluster from the USA and an honorary degree from the University of Cambridge. He returned to Wisconsin in 1945 and remained Dean until 1953. He then was appointed Chief Medical Director of the Veterans Administration in Washington DC, overseeing the 273 VA hospitals that served 106,000 patients per day. The VA research program grew from $\$ 6.4$ million to $\$ 30.5$ million during his tenure. Upon Dr. Middleton's retirement, President John F. Kennedy thanked him for his lifetime service to the soldiers and the veterans that served our country. The Middleton Medical Library next to the Wisconsin General Hospital was opened in 1967. The Madison Veteran's hospital was renamed the William Middleton VA Medical Center.

Judith Faulkner MS (1943) Founder EPIC Systems, Lecturer Department of Computer Science

Judith was born and raised in Cherry Hills, NJ. She graduated from high school at age 15 and Dr. Middleton, now Colonel Middleton, received a BS in mathematics from Dickenson College in 1969. She received an MS in computer science from the UW in 1978. Upon graduation she borrowed $\$ 70,000$ from friends and family and with Dr. John Greis started a company, Human Service Computing which became EPIC Systems. EPIC is a healthcare software provider, now located in Verona, Madison. It is now the largest system of computerized medical records, used by many major healthcare systems including Kaiser of California, Mayo Clinic, UCLA, and UW Madison. The system records medical visits, laboratory reports treatments, pharmacy orders, future appointments and billing and insurance information, all available to the patient and to the health care team, locally and at other medical facilities. EPIC is also used in an increasing number in other countries including the UK, The Netherlands, Australia, and Singapore. The Verona campus has 8 buildings and employs 10,000 people. The company's large work force is gender, ethnic, religion and attire neutral. Indeed their dress code states "When you have visitors, you must wear clothes." Their slogan: "Do good, Work hard, Have fun, Make money." EPIC has improved the economy of the Madison, Wisconsin area; for example flights in and out of the Dane County airport have increased dramatically as EPIC employees visit multiple medical centers for training and updates. Ms. Faulkner recently stepped down as the CEO of the company She has participated in The Giving Pledge, promising to donate most of her wealth to a worthwhile philanthropic organization.

\section{Summary}

These 13 individuals have collectively improved the science and practice of medicine throughout the world. The demographics of the group indicate that five were born in Wisconsin and eight received part or all their education at the University. Two were foreign born (Khorana and Belzer) and six were aided in their research by the Wisconsin Alumni Research Foundation. Two became University Presidents (Elvehjem and Lederberg). Three received a Nobel Prize (Khorana, Temin and Lederberg).

All brought honor to the University. 